\title{
Forgiveness as Potentiality in Criminal Justice
}

Aaron Pycroft

\section{University of Portsmouth UK}

Clemens Bartollas

\section{University of Northern lowa}

\begin{abstract}
To explore the problematic of forgiveness in criminal justice we argue for and utilise the deep homologies that exist between the continental philosophical tradition and approaches to complexity theory (the potential to realise new dynamical states). Through taking a hermeneutical narrative approach we argue that studied together they provide us with new insights into questions of punishment, retribution and rehabilitation and enable us to better understand the connections that exist between victims of crime, perpetrators and the community through examination of the content of dominant narratives that emerge in the historical relationship between theology and law; gain insight into an increased path lock (entropic justice) with respect to retribution in liberal democracies such as the USA and UK based upon decomposition of the Judaeo-Christian message; and examine what contemporary stories of forgiveness reveal with respect to accessing new dynamical states and new ways of doing justice that challenge dominant and reductionist narrative.
\end{abstract}

\section{Introduction}

In examining the concept of forgiveness we do so with some trepidation and conscious of Spinoza's dictum that all determination is negation (see e.g. Melamed, 2012) i.e. the more that we examine the concept and seek to reduce it to component parts the less we are able to say what it is; it is an irreducible concept. Different methods are required then to explore the elusive problematic of forgiveness in criminal justice and to achieve this we tentatively seek to argue for and utilise the deep homologies that exist between the continental philosophical tradition and approaches to complexity theory. Our approach is one of hermeneutical narrative in which we seek to bring new resources to our criminological perspective through occupying liminal spaces and "Where one tries to get one's bearings as 
one transits between two (or more) worlds" (Kearney, 2011: xvii). This process is always uncertain, un-finalizable and inevitably partial and therefore difficult but we seek to engage with diverse thinkers and traditions who have the potential to offer significant insights to criminology and the practices of justice to further important dialogue.

We argue for a conceptualisation of forgiveness as an expression of multiplicity in unity (it is more than the sum of its parts) and which is rooted in the irreducible and emergent relationships between the victim, the perpetrator and wider society and to argue therefore that it is not possible to tell one exclusive story (dominant narrative) about forgiveness; to reduce our explanatory perspective to one of either victim, perpetrator or community is to decompose the system. We argue that this approach enables us to: (1) understand the connections that exist between these actors through the content of dominant narrative that emerges in the historical relationship between theology and law (2) gain insight into an increased path lock (entropic justice) with respect to retribution in liberal democracies such as the USA and UK based upon decomposition of the Judaeo-Christian message and (3) examine what contemporary stories ${ }^{1}$ of forgiveness reveal with respect to accessing new dynamical states and new ways of doing justice that challenge that dominant and reductionist narrative.

Both forgiveness and retribution imply the creation of a new moral community informed by but not anchored in the past (Verdeja, 2004:39) but we argue for a new teleological perspective in criminology which addresses the importance of the arrow of time, past, present and future and which avoids a collapse into utilitarian pragmatism ${ }^{2}$. This teleological

\footnotetext{
${ }^{1}$ We take narrative to imply the "top down" need for control and stories as the "bottom up" demand for ethics (see Verdeja, 2004).

${ }^{2}$ The Utilitarian concepts of less eligibility (see Sieh, 1989) and risk management render the future unrealizable through a closing down of opportunity and potential through the removal of resources that would allow for
} 
perspective is grounded in choice which is implicitly and explicitly ethical. This choice is then

the potential for the creation of a new and positive virtual image of perpetrators of crime that can be projected and actualised in a telos of now. We argue that forgiveness is the dynamic and emergent space onto which these identities are projected in and through time. Our approach is to argue that forgiveness cannot be amnesia but rather that allows for the past (the crime itself and its impact), the present (the practices of justice) and the future (the potential of becoming) to be revealed ${ }^{3}$. We re-examine foundational Christian texts in the light of developments in both hermeneutical approaches to complexity theory and continental philosophy to provide examples of forgiveness that challenge instrumentalism at the service of final, entropic categories of justice which undermine (by an effective closing down) the possibilities of becoming and the accessing of new dynamical states for victims, perpetrators and communities.

\section{Continental philosophy, hermeneutics and complexity theory}

We take continental philosophy as different from analytic philosophy and rejecting of the latter's emphases on positivist and empiricist perspectives ${ }^{4}$. Whilst the continuities and discontinuities of these two traditions are much debated we use Critchley's argument

\footnotetext{
the potential to access new dynamical states. This is entropic and self-defeating practice as it contains an essential nihilism in that firstly it assumes the rationality of individual actors and therefore the collective calculus of the greatest happiness for the greatest number to be correct, even presumably in the justification of collective violence; but secondly because we cannot say with any certainty in the face of human passions (proclaimed as justified and requiring of satisfaction) precisely where, what or when the end is that truly justifies the means. This problem of the entropic nature of utilitarian eschatology is stated by Nelson (Nelson, 1991: 339) when he says that utilitarianism "Implies a surprising prediction about the future, viz, that all experience of pleasure and pain must end once and for all, or infinitely dwindle."

${ }^{3}$ This approach also rejects dialectical method (the negation of the negation) whereby the past is synthetically dissolved in the creation of a new reality. Complexity theory demonstrates that all complex systems are historical systems that influence the present (see below).

${ }^{4}$ See Arrigo and Williams (2014) on the relationships between complexity theory, continental philosophy and Psychological Jurisprudence in criminology
} 
(Critchley, 1997:355) that the continental tradition “...takes the form of a critical (emphasis in the original) confrontation with the history of philosophy...with...a critical dismantling of the tradition in terms of what has been unthought and what remains to be thought." Critchley (Critchley, 1997: 356) argues that this leads to "the demand for a transformative practice of philosophy, art, poetry or thinking...that would be capable of addressing, criticizing and ultimately redeeming the present."

With respect to this continental tradition and the philosophy of complexity theory Paul Cilliers (Cilliers, 1998, 2005) argues that both deconstruction and complexity reveals both the limits of our knowledge and the irreducibility of meaning but in a non-relativistic way ${ }^{5}$. This limitation is brought about because we inhabit the systems that we study and therefore we can have no absolute and objective knowledge of our lived experience. Meaning and knowledge is contingent and contextual and because it cannot be represented and the context is not transparent we have to choose our hermeneutical frameworks but ultimately "A radical 'undecidability' surrounds all signification; there can be no absolute origin or site of meeting." (Kearney and Rainwater, 1996:439). It is due to this choice, Cilliers argues that we cannot escape what is ethical or normative.

Christian scriptures are key texts that have had a dominant but contradictory hegemony (or in the Derridan sense of instability of signs) and importantly in the development of the modern state and apparatus of justice. These historical transformations (bifurcations) are demonstrated through the evolution of resources that are foundational to a Jewish sect committed to radical forgiveness and non-violence through time becoming a justification for

\footnotetext{
${ }^{5}$ It is beyond the scope of this paper to discuss the existence of absolutes in the platonic sense and as utilized in scientific method but see Pycroft (forthcoming) for a discussion of the relationships between phenomenology, complexity theory and criminology
} 
punishment and retribution; so much so that the use of these non-violent resources are now controversial in for example restorative justice due to their perceived retributive nature (see Johnstone and Ness, 2007) and religion and punitive ideology would seem to be strongly correlated (e.g. see Baker and Booth, 2016). A hermeneutical approach as a development of continental philosophy helps us to re-examine these texts within the context of their traditions and the hermeneutical circles that are created through those traditions that identify the core texts which are then used to legitimate their activities (see Pellauer and Dauenhauer, 2016). In utilizing insights from hermeneutics we will follow the work of Paul Ricoeur in advancing from a hermeneutic of suspicion to one of affirmation (see Kearney, 1986).

Complexity theory itself divides along traditional ontological, epistemological and methodological lines in science, social science and social theory with debates examining the relationships between mathematically deterministic and constructionist approaches (see Pycroft and Bartollas, 2014). However broadly speaking complexity theory in its nonreductionist (whole systems ${ }^{6}$ ) approach contrasts to the Newtonian paradigm and its positivist (and analytical philosophical) assumptions enshrined in criminal justice and reflects the argument of Milovanovic (Milovanovic, 2014) that approaches to criminal justice grounded in Newtonian thinking and method are lacking in any bone fide statement on human agency. Complexity theory demonstrates that all systems such as justice systems are driven from the bottom up, by lower order interactions from which the whole system emerges. To understand the nature and behaviour of complex systems reductionist and

\footnotetext{
${ }^{6}$ The language of whole systems can be ethically problematic. We use it as a contrast to the reductionism inherent in positivism and in the sense that Levinas would distinguish between totalizers and infinitizers; with the former being satisfied with themselves and the systems they can organize and control and the latter being dissatisfied and who strive for what is other than themselves (see Levinas, 1969)
} 
positivist experimental methodologies reified by positivist approaches are ineffective, as when we abstract from the whole to the part, we can only understand the part and not the whole. We are interested to take an approach which rather than reducing and separating component parts in the practice of justice (e.g. prioritizing retributive passions and the demand of justice on the part of victims and communities or asserting the primacy of rehabilitation in reducing crime) look to the ways in which they interact together and coconstitute each other. Complex systems allow us to confront history as they are historical systems with a memory and which we are constitutive of. We look then to a post Newtonian (post-positivist) account of justice based upon an ontological and epistemological understanding of conjunction (connectionism and emergence) rather than disjunction (reductionism and closing off). As Bartollas (Bartollas, 2014:276) argues:

A post-positivist understanding sees community as an extension of neither individualism nor collectivism. The intrinsic nature of community, according to a post-positivist's view, denies the notion that individuals profit by serving themselves or that individuals can only define themselves through a collective movement. Fostering community does not require participants to lose themselves, but to join with others to become more than themselves. ${ }^{7}$

These non-totalising perspectives recognise the heterogeneity of the whole system that allows for new dynamical spaces to be created which may challenge the dominant

\footnotetext{
${ }^{7}$ Our approach is consistent with Peacemaking Criminology which to quote Hal Pepinksy (Pepinksy, 2013:320) is concerned with "How to transform violence into cooperation, of how to make peace from the intrapersonal to global levels... (building)... on literature from all manner of sources...most of which is by folks who do not call themselves criminologists either... and a concern for understanding how to transform violence transcends normal academic boundaries." Our approach is also consistent with Pepinsky's argument (2013) that Peacemaking Criminology also understands that in crime and criminality there is no political neutrality and that people are locked in set agendas; that stories are data for understanding the social construction of crime; that you cannot impose peacemaking; that peacemaking acts as an attractor (see below) spawning empathy and compassion; outcomes from peacemaking are very uncertain with results not always known.
} 
(deterministic) narratives of justice from the bottom up and through an open ended commitment to the enhancement of non-linearity in the forms of uncertainty, undecidability and unfinalizability. Forgiveness is exemplary of non-linearity as it is not proportionate to a crime committed, cannot be required, and may be unlooked for (by victims, perpetrators and communities).

The following principles of complexity theory are most significant for our discussion in relation to forgiveness (for a full discussion of the principles in themselves see Pycroft and Bartollas, 2014; Arrigo and Barrett, 2008; Byrne, 1998; Cilliers, 1998) and we argue demonstrate the ways in which history (1) potentially becomes locked into particular narratives but also (2) allows for the creation of new possibilities and dynamical states.

\section{The Arrow of Time}

Due to being open systems complex systems such as justice systems are subject to the arrow to time. A key feature of Newtonian mechanics is that time is reversible whereas complexity theory demonstrates that this is not the case, that the material causes of the past cannot be changed because systems are constantly in evolutionary flux, and moving forward. Our concern is with the ways in which time and the problem of irreversibility is experienced by victims, perpetrators and wider society. Bergson (Bergson, 1971, 1988) argues that the past cannot be changed but its virtual dimensions can be. This is expressed by Žižek (Žižek, 2011: 28) as "When something radically new emerges it retroactively creates its own possibility, its own causes or conditions. A potentiality can be inserted into (or withdrawn from) past reality." The arrow of time is central to discussions on forgiveness as the material past cannot be changed (Arendt, 1958) but the emergent (transcendent/virtual) properties inherent 
within complex systems allow us to address those issues because the whole is always more than the sum of its parts.

\section{Iteration and path dependence}

Modern justice systems are founded and grounded in features and functions that have founding myths and including in the practice of rehabilitation. Historical practice has woven together the exercise of utilitarian power (myths of rationality and social contract giving rise to concepts of less eligibility and risk assessment) alongside the explicitly theological language of rehabilitation (the virtues of hope and making good focusing on pro-social attitudes to access social capital). As Hathaway (Hathaway, 2003) argues it is impossible to understand the law as it is practiced now without understanding the law as it has been practiced in the past. Hathaway in examining the role of history in law highlights the importance of tradition in constitutional interpretation, the role of historical narrative in decision making and the value of precedent. Furthermore advances in complexity theory demonstrate the nature of cultural and organizational path dependence with Sydow et al (Sydow et al, 2009) arguing that the process has the following properties: that outcomes are unpredictable and indeterminate; that several outcomes are possible and that history selects from the alternatives; trapped actors cannot shift the patterns once established; the path lock eventually leads to inferior and sub optimal outcomes (entropy). So with respect to the practices of criminal justice we would argue that an overt focus on retribution and punishment is not the only possible outcome from the interaction of processes under consideration, but we need to understand how this path lock has emerged and how it can be shifted. To use the language of Deleuze and Guattari (see Massumi, 1996) punishment in the forms of retribution and incarceration has reached a plateau of intensity that is not 
automatically dissipated in a climax leading to a state of rest. In practice there is a heightening of energies which are sustained and dynamic enough to appropriate from each other and weave together to form any number of different reinforcing connections.

\section{Sensitivity to initial conditions and bifurcations}

Very small changes in the lower order interactions of a complex system can have a massive impact on the system overall. These are the emergent properties of the system which cannot be predicted or mapped mathematically as it is always more than the sum of its parts (transcendent properties). These small changes may lead to changes in the trajectory of the system and the accessing of new dynamical states. The development of the Jewish sect that became Christianity and its influence on the development of modern states and (amongst other things) justice systems are examples of this that we discuss below. What becomes evident is precisely the instability of Christian ${ }^{8}$ signs of forgiveness across history and the ways in which they can become appropriated and subverted to very different ends.

\section{Attractor states}

Attractors are like magnets that pull/push systems in particular directions in time and space and which exhibit regularities and apparent patterns of stability (chaotic, edge of chaos and equilibrium). Due to its highly mathematical nature attractor theory (see Guastello and Liebovitch, 2009) has been contentious in postmodern conceptions of complexity with for example Cilliers (Cilliers, 1998) arguing that they are another aspect of reductionism that do

\footnotetext{
${ }^{8}$ Our focus is on Judeo-Christian theology as being foundational to modern western societies and legal systems, however we also acknowledge the importance of Islamic culture and science to that development from the $7^{\text {th }}$ Century CE onwards, not least in rediscovery of ancient Greek philosophy through the work of Ibn Sinnā which did much to invigorate scholastic thought; Thomas Aquinas referred to him as "The Commentator." The contribution of Islamic thought to understandings of forgiveness and its relationship to Christianity and western culture is an important area for development and research. See Menocal (2002).
} 
not sufficiently address aspects of the whole system. However within hermeneutics and social theory there has been an interest in strange attractors (for example in the work of Deleuze and Guattari (see Massumi, 1996). A strange (sometimes called chaotic) attractor is one in which there are patterns and regularities but the system never follows the same trajectory (see Pycroft, 2014). There are processes of both expansion and contraction and the chaotic motion operates in more than one dimension. There is order and control although each order parameter is affected by the behaviour of other order parameters. These attractors are prone to bifurcate, that is become increasingly complex by accessing new dynamical states in their environment; this is effect and effect rather than cause and effect. This makes the evolution of the whole system and its trajectories fundamentally uncertain. Hermeneutically strange attractors are examples of qualitative multiplicities, containing infinite possibilities that are not foreseeable, with the realisation of the possible only existing in retrospect. This then allows for understanding the divergence and convergence and complexity of human lived experience grounded in relational time.

Girard's (e.g. Girard, 1978, 1999) scapegoating thesis is highly compatible with complexity and attractor theory as his approach charts the ways in which groups, communities, societies achieve equilibrium through the scapegoating mechanism: Faced with some crisis (chaos) the use of violence against the apparent perpetrator of the crisis (edge of chaos) restores equilibrium to the community. Scapegoating serves as a fundamental cultural attractor that arises from our evolutionary inheritance. Girard's is a theory grounded in the mimetic nature of desire and human passions. His idea is that in desiring what others have then we model ourselves on those people who then become our rivals, and which leads to periodic outbreaks of mimetic violence; this violence is constrained in unequal societies but particularly comes 
to the fore when dominant groups find themselves in positions of economic and social equality with minority groups. With respect to criminal justice the Girardian perspective helps us to further understand the locking in of revenge and retribution: For example with respect to victims and perpetrators under the justice model once punishment is completed the perpetrator is now innocent and justly expectant of the rights and resources of society to be restored or given to them. However it is this that brings about a mimetic crisis leading to the scapegoating of ex-offenders who for legal purposes are now innocent. The form that this scapegoating takes is enshrined in utilitarian teleology (the concepts of less eligibility and risk managements and reinforced by satisfaction theory (discussed below) by maintaining that the violence inherent in the continued denunciation by the community ostensibly in support of the original victim is justified over and above the rights of the person who has served their punishment on the basis of the further risks that they might present and the necessity of a deterrent effect.

\section{Dissipative structures}

Forgiveness and its relationship to the energy of human passions within criminal justice has been discussed by Murphy and Hampton (Murphy and Hampton, 1988) and Lacey and Pickard (Lacey and Pickard, 2015) whereby the desire for justice on the part of victims and communities are used to reinforce punitive models of justice. Energy is the key analogy in complex systems (see Pycroft, 2014; Byrne, 1998) and complex systems are open systems constantly interacting with their environment to gain new energy, to enhance that energy and then to dissipate it back into the environment. At times the environment may deprive the system of energy or overload it thus driving change (Byrne and Callaghan, 2014) by providing critical levels of disorder which not only (potentially) break down but also allow for 
spontaneous and novel forms of re-organization (Williams and Arrigo, 2002). In our argument and in terms of radical and transformative justice we can utilize Bergson's (Bergson, 1988) development of Aristotle's conception of potentiality (dunamis) and its relationship to actuality (energeia) which rather than being concerned with someone's power to produce a change (e.g. to make good through voluntary contrition, or to impose punishment to coerce contrition) is their capacity to be in a different and more completed state (Cohen, 2016) and enabled to be so through the actions of both the victim and the community.

\section{Forgiveness}

Having established our approach we now look to developments in the study of the concept of forgiveness itself. A main focus of studies in forgiveness have been theological but perhaps due to a resurgence in interest in Aristotelian virtue ethics (e.g. Anscombe, 1958) had also seen increased philosophical interest in the late $20^{\text {th }}$ Century ${ }^{9}$ (e.g. Kolnai, 1974, Downie, 1965). It was Griswold's work (Griswold, 2007) that challenged the Judaeo-Christian hegemony in debates on forgiveness by re-examining Greek and Roman sources. However a re-examination of these debates particularly with respect to the person and theology of St Paul $^{10}$ demonstrates some interesting and challenging perspectives.

The secular Jewish philosopher Hannah Arendt argued that Jesus of Nazareth discovered the role of forgiveness in human affairs (Arendt, 1958) however this is challenged by Griswold (Griswold, 2007) who argues that she overstates the case as he finds significant evidence for concepts of forgiveness already existing in pre-Christian Greco-Roman culture. The ancient

\footnotetext{
${ }^{9}$ There has been significant interest in criminal justice e.g. in the development of Psychological Jurisprudence (see Arrigo and Williams, 2014)) and also the Good Lives Model (Ward and Maruna, 2007)

${ }^{10}$ The person and theology of St Paul has become a key area of scholarship in continental philosophy; see e.g. Badiou (2003); Breton (2011); Azzam (2015); Kearney (2016).
} 
Greeks did not have a word for forgiveness; Aristotle used a range of words associated with the verb sungignosko relating to think with, agree with, recognize; all are linked with notions of relationship and empathy (see Griswold, 2007). However for Aristotle forgiveness is neither a virtue or religiously based but rather it is linked to civic politics (see Bash, 2014). The key is to be found in Aristotle's concept of unbearable circumstance (Aristotle, 2004) which is linked to a perfectionist ethical stance linked to external forces. The virtuous, detached and rational man does not make mistakes and can be excused for events outside of his control, hence no forgiveness is required. But importantly any sense of empathy does not extend to un-virtuous persons and the irrationality of the "mob."

Bash (Bash, 2014) highlights that within the New Testament there are differences between the Gospels and the Pauline epistles concerning the nature of forgiveness. Both Jesus of Nazareth and Paul of Tarsus challenge the link between ritual conceptions of purity, sin and forgiveness and both argue that there is an injunction on Christians to forgive. However in the Synoptic Gospels there is an emphasis by Jesus on interpersonal forgiveness, whereby repentance is necessary to be forgiven by God, but likewise to be forgiven it is necessary to forgive others, as in the following (the Hebrew verb used is Aphiemi which has a legal connotation of acquitting, a sense of release, to excuse and cancel a debt):

"Then Peter went up to him and said 'Lord, how often must I forgive my brother if he wrongs me? As often as seven times?" Jesus answered, 'Not seven I tell you, but seventy-seven times." (Matthew 18 verses 21-22, New Jerusalem Bible: 1130):

In contrast the point is made by Bash (Bash, 2015) that Paul of Tarsus whose epistles constitute a significant proportion of the New Testament is not a theologian of forgiveness (he rarely mentions the word) but one of justification and by justification he means a gift of 
grace to undeserving people. This is interesting because despite Paul being a Hellenised Jew with the expectation that he would use sungignosko type concepts he actually uses the Hebrew charizmoi to express gifts of grace (Bash, 2014). In this sense rather than the requirements of the gospels to be forgiven through forgiving, it would seem that Paul in arguing that a justified people are a forgiven people and that even the desire to repent is as a consequence of a gift of grace, is arguing for the community to forgive as an act and expression of grace.

The Pauline approach is in part a reflection of Paul's own experience (see also Breton, 2011). He had been a persecutor of the early Jews who joined the emerging Christian church and he was complicit in the stoning to death of Stephen a Christian disciple and which seems to have led to Paul's conversion to Christianity (Acts Chapters 7-9). In Acts the story goes on to show how afraid the people were of Paul after his sudden conversion, including the leaders of the church, but when another Apostle named Barnabas (and interestingly the name Bar-Nabas is translated as both Son of Encouragement and Son of Consolation) advocated for him, he was accepted (Acts 9 vv 26-30) hesitantly into the community of Christians but went on to become the key Apostle to the Gentiles, promulgating Christianity throughout the Middle and Near East. A reading of the Pauline story reveals especially the conversion "Event" (see Badiou, 1986) is instructive as at no point was he asked to repent, or humiliate himself before the community, neither was he required to make atonement so that the community were satisfied as to his intentions. But equally as importantly Paul did not try to hide or to justify his past and we can infer from the text that his past was a key component in the emergence of a new identity (Saul becomes Paul). In this experience (Acts 9 vv1-7) he is only asked one question by Jesus "Saul, Saul why do you persecute me?" to which the only response that Saul 
has is to ask who is speaking to him, and to which Jesus responds with his name and to tell Saul to follow the directions given to him. His new identify is a gift rather than something earned.

This idea of gift stands in stark contrast to contemporaneous practices of justice and the Authentic Apology Model (Allan, 2008) which enshrines a functionalist approach to the forgiveness of a perpetrator of a crime or a civic offence with the onus on the wrong doer to explain their wrongful behaviour and to accept liability; to experience an emotional response to the wrong and to action behaviour to right the wrongs done. Allan (Allan, 2008) in asserting this approach argues that criminal law and punishment is fundamental to social order and equilibrium and reinforces those processes through also deterrence and offering the possibility of rehabilitation. For Allan apology is central to the process of rehabilitation by allowing the wrongdoer to humiliate themselves and to show respect to victims and society and therefore demonstrate that they are not of bad character.

\section{Atonement and social order - a hermeneutic of suspicion}

Hermeneutics and the work of Ricoeur helps us to examine the relationships between ideology and religion and the ways in which an "Ideological recollection of sacred foundational acts has the purpose ...of integrating and justifying a social order" (Kearney, 1986:112) and to address the question of how in societies whose cultural identity is rooted in the Judaeo-Christian tradition we have moved from these radical, creative and radically reinforcing stories of forgiveness and grace to those of a dominant, locked and dampening narrative of conditionality; and whereby the original meanings of these texts are obscured to the extent that for examples within debates on restorative justice forgiveness is controversial and perhaps lacks an articulation of meaning and philosophical resources (see Armour and 
Umbreit, 2005)? Ricoeur's hermeneutic of suspicion seeks to recover repressed meanings. A key factor in the repression of original meanings was the historical convergence of Christian theological notions of forgiveness becoming inextricably linked with theories of atonement.

Prior to Anselm of Canterbury (1033-1109) a Christus Victor theology saw mankind as being in bondage and held hostage to the evil powers of Sin, Death and the Devil. This is not dissimilar to Aristotle's idea of unbearable circumstances however under this human focussed theology (see Eddy and Beilby, 2006) Christ frees mankind from those circumstances irrespective of their purity or rationality (Aulen, 2010). Aulen (2010) argues that this theology was rich in imagery and metaphor but was displaced by a more 'rational', approach based on satisfaction theory. Satisfaction theory is Godward looking (Eddy and Beilby, 2006) and argues that the justification for punishment and retribution is that God Himself is punitive and demands satisfaction through sacrifice and punishment for every sin so as to make atonement. These fundamental changes (bifurcation) in theological thinking coincide with the rediscovery of Greek philosophy by Islamic and Christian Scholastics; hence the Aristotelian influence of purity and elitism becomes apparent. This idea had also been reinforced by Augustine's earlier Platonic ideas in the City of God (Augustine, 1958) that the State is a bulwark against sin. In this historical development and in seeking to understand why liberal democracies that have had a Christian identity are so punitive in their approaches to criminal justice, contra biblical accounts of forgiveness Gorringe (Gorringe, 1996) argues that religion and law are related at the deepest level and that,

"Christian theology constituted the most potent form of ideology in western society for at least a thousand years up to the $18^{\text {th }} / 19^{\text {th }}$ centuries and its ideological importance is by no means dead. It was both influenced by, and influenced, penal thinking. It represented a 
construal of the crucifixion of Christ, by no means inevitable, which reinforced retributive thinking, according to which sin or crimes have to be punished and cannot be dealt with in any other way."

Gorringe argues that satisfaction theory emerged in the $11^{\text {th }}$ century at the same time as criminal law took shape, and reacted on each other with theology drawing on legal notions and law looking for metaphysical justification. The contrast between the two approaches is significant as in Satisfaction Theory Christ is the only acceptable sacrifice to an angry God who demands retribution, whereas Christus Victor is a freely given act of love from God, in the face of unbearable circumstances for mankind e.g. "the gift of grace expressed in the Pauline letters, and the cross of Christ is not a justification of punishment but a heralding of its end" (Gorringe, 1996: 269). The rediscovery of Greek philosophy by the medieval Scholastics may have provided a framework for establishing a purely rational theology but in so doing discarded the dramatic symbolism of classical atonement. Thus, perhaps unwittingly a theology of difference and individualisation that reinstated a Greek view of unbearable circumstances and purity alongside Christian notions of sin, penance and satisfaction was introduced that negated the Biblical view of the powerlessness of Everyman and the need for outside and freely given help (grace).

This philosophically informed approach to theology has been essential to the creation of a hegemonic and state sponsored Christian religion, fundamental to social order, and therefore complicit in cruelty, punishment and the exercise of power. It is argued by Martin (Martin, 2014:42) that:

"It is not in the least surprising that Christianity devised strategies of negotiation, compromise and assimilation as it spread in societies characterised by discourses of power and codes of 
honour. On the contrary, the history of Christianity...follows precisely the course you would expect...the presentation of Christianity was often loaded towards the Old Testament, so that rulers fashioned their self-understanding in the image of Solomon, David, Hezekiah or Josiah. Appropriations of the figure of Christ crucified by monarchs and ecclesiastics were much less popular because less plausible and persuasive, except when deployed at tangents that ignored the stripping away of the human dignity of Christ by the legally constituted authorities in 'Church' and state. The Godly Prince of the Renaissance ruling jure divino found scant gratification in the role of a convicted felon."

Girard (Girard, 1978) along with Nietzsche (Nietzsche, 2003, 2008) and Foucault (Foucault, 1975 ) is concerned with the ways in which cruelty is linked to the exercise of power and ideology. It is clear that violent interpretation (or rather subversion) of scriptural texts are used to justify violence and punishment. So whereas Foucault focuses on disciplinary technologies and normative social science that expel the old rituals of violent expiation, Nietzsche and Girard find evidence of those continued mechanisms which are revealed through myths and literature, ancient and modern. The meeting of the thought of Nietzsche and Girard are we argue the key fault lines in understanding the relationship between collective violence, social order and religion. For Girard the Judeo-Christian tradition and gospels reveal a genuine epistemology of love, forgiveness and non-violence, whereas for Nietzsche at best they reinforce the links between religion and justified violence.

Girard argues (Girard, 1978, 2008) that scapegoat rituals are the process by which violence is contained and resolved in societies and is linked with religious rituals. Girard identifies the scapegoat mechanism as being behind every ritual including those of justice, punishment and denunciation (Girard 1978). Likewise Dupuy (Dupuy, 2013) observes that with the decline of 
the twin pillars of religion and monarchy justice is the only publicly ubiquitous ritual that advanced industrial countries have left. What is significant and controversial about Girard's theory and what differs from traditional anthropological accounts of scapegoating (e.g. Frazier, 1922) is his psycho-analytically informed argument that scapegoating should not be seen as a conscious activity based on a conscious choice. The process is effective precisely because there is an element of delusion to which we are all susceptible, so all of us can condemn examples of scapegoating yet none of us can identify our own involvement in it. Girard (Girard, 2008) argues that the scapegoat is a coherent enough interpretation of all rituals that resemble the Leviticus ritual. In the Mosaic ritual of the Day of Atonement (Leviticus 16) the scapegoat is that one of the two goats chosen by lot to be sent alive into the wilderness, the sins of the people having been symbolically laid upon it, while the other was appointed to be sacrificed. Whether physical or psychological the violence directed at the victim appears to be justified because the scapegoated person has brought about some evil that must be avenged, resisted and oppressed. History and contemporaneous societies are replete with examples and in addressing mimetic violence and social disorder the scapegoat restores order through becoming the focus for retribution and denunciation. A social dimension is always present, with persecutors a majority and their victims a minority and implies a process of displacement or transference and reveals the unconscious dimensions of social order. This is clearly expressed by Jesus who during his crucifixion stated "Father forgive them, they do not know what they are doing." (Luke $23 \vee 34$ ); likewise as he is being stoned to death Stephen "...knelt down and said aloud, 'Lord do not hold this sin against them." (Acts 7 v 60). Girard (Girard, 2014) argues that in scapegoating the victim is always innocent in the face of the violent collective, and that Christianity has taken the side of innocent victims (for example in the judicial execution of Jesus of Nazareth who was innocent but was the chosen 
scapegoat to restore social order in a Jerusalem at threat of violent unrest) whereas as Nietzsche for example sees this as nothing more than revenge by the weak against the strong, a Christian slave mentality indicated by forgiveness which in itself was nothing more than a form of revenge (Nietzsche,2008).

Girard then reveals much of what has become hidden or obscured in the historical development and practice of Christian narrative. In the words of Richard Kearney (Kearney, 1999:252):

"Girard seeks accordingly to make the operations of our social imaginary - i.e. our ideological unconscious - answerable to ethics. He resolves to subject ideologies of scapegoating to a critical hermeneutics of suspicion, exposing concealed meanings behind apparent ones...sacrificial figures though invariably aliens and excoriated by their contemporaries become hallowed over the ages until they are eventually remembered as saviour gods who restored their community from chaos to order. They emerge out of the mists of time as miraculous 'others' who managed to transmute conflict into law. But this miraculous alteration of sacrificed 'aliens' into sacred 'others' is predicated upon a strategic forgetfulness of their original stigmatisation..."

\section{Forgiveness, accessing new dynamical states - a hermeneutic of affirmation}

A hermeneutic of suspicion allows us to revisit texts and messages which have become obscured, subverted and locked in through historical violence and which potentially offers an alternative to that violence. These sources demonstrate that we are all complicit in scapegoating and violence but also offer us the potential for new and creative spaces; a way out of our violence. So in contrast with the current conceptualisation implying that only 
retribution acknowledges guilt and therefore personal responsibility (and the claim that we are justified and responsible in our retribution) Gorringe (Gorringe, 1996) argues that this is also implicit within any act of forgiveness. He states that this brings about a paradigm shift that has the potential to change the past and the future and therefore perceptions and roles and regulations too and we would add challenge the highly deterministic locking in of retribution to justice systems.

This approach fits with De Valve's argument that justice is what love gives us (De Valve, 2017b:384) that we need new approaches that "must be an individualization that facilitates a full actualization and celebration of the individual, but through the mutual action of the community." Furthermore in exploring the dynamics of peaceful rebellion he argues (De Valve, 2017a: 98) that justice is a sacrament in the form of an outward and behavioural symbol which is "a boundary-spanning event." This is St Paul's conception of grace in action, a hermeneutic of affirmation (see Kearney, 1986) which can be conceptualised and realised in diverse ways:

For Gorringe (Gorringe, 1996) forgiveness is a space of a hard fought praxis as demonstrated by the example of Terri Roberts (Roberts with Windle, 2015) and her recounting of her Son Charlie Roberts and his shooting of 10 Amish girls in a school house in Pennsylvania in 2006. Five girls were murdered the others seriously injured and then he killed himself. Immediately following the shooting the Amish Bishop extended forgiveness to the killer. What is remarkable about this account is the ways in which the Amish community including the parents of the killed and injured children reached out to Terri Roberts and her family despite the pain, anguish and grief that they were feeling. Over time it became possible to establish solid relationships both with parents, other members of the community and the surviving 
children. There is one example from the book that both practically and symbolically represents the movement of the injured individuals and the community towards the perpetrator and his family: Charlie Roberts himself was to be buried with a quiet service in a cemetery away from the town in which he lived and the massacre occurred. The Roberts family were assured by the police of complete privacy and no press intrusion, but as they arrived at the cemetery the media were present in large numbers. However unbeknown to the family the Amish community were also there and they surrounded the family and the burial so that the view for the media was disrupted.

Arendt (Arendt, 1961) in discussing the arrow of time argues that both the past and the future are forces which act on the present, and that the person is inserted not into this time but into a gap in time which is kept in existence by a constant fight against past and future. It is in this gap that we can insert new beginnings (natality) by differentiating between time and space; our freedom is dissociated from time and associated with space. Importantly we are not talking here of a timeless, idealised, Platonic space but one that has a spatial dimension (Arendt, 1961) as seen in the following example. Daniel Poskitt's sister had been murdered by her boyfriend who was convicted and imprisoned. After 10 years they had the opportunity for a victim-offender conference:

"We all had the opportunity to talk, to ask questions. "Why did you kill Karen? What were you thinking?" He had no answers for us; he said he didn't know why he killed her and that he couldn't remember the details of that day. For our family, this was unacceptable - we had come for answers. My father was angry and I felt angry too. Dad stood up and demanded that he tell us why. A ball of anger formed in the pit of my stomach and forced itself up and out of my mouth. I stood up and shouted: "You fucking coward." It felt good, really good, to get that 
anger out after 10 years. I didn't even know I had it, but I knew after it came out. For me, it was a healing experience. It allowed me to let go of the anger and see the world differently. It didn't bring back Karen but it did bring me back to a point where I can now forgive him. That may sound strange to some people, but I've learnt that forgiveness is not about the perpetrator, it about you. It's about you letting go of the stuff that holds you back so you can live hapy and fulfilling life." (http://www.theguardian.com/commentisfree/2015/nov/03/i-was-able-to-forgive-mysisters-murderer-only-by-acknowledging-my-own-anger

For Bergson (Bergson and Andison, 2010) intuition is a creative leap, and both opposed to platonic reconstitution after analysis, by moving forward rather than looking backwards, but also seeing the possibility of new beginnings (telos), now, rather than at some time in the future. This is demonstrated in the trial of Oscar Groning who was an SS Guard at Auschwitz and who kept records of the belongings that were confiscated from the prisoners when they were brought to the camp. Groning had never denied his guilt but was brought to trial due to a change in the law that allowed for his prosecution. During the trial Eva Kor who had been a prisoner in Auschwitz, and along with Miriam her twin sister had been experimented on by Josef Mengele publicly forgave Groning. After giving her testimony she walked across the court room, shook his hand and embraced him. Afterwards she said that this had not been planned and added:

"I wanted to thank him for having some human decency in accepting responsibility for what he has done. I was always interested in meeting him face to face because I believe that there is a human interaction that I cannot predict and no one else can predict." 
(http://www.theguardian.com/world/2015/apr/27/auschwitz-survivor-angers-plaintiffs-

trial-forgiveness)

Eva Kor claimed that Groning was so overwhelmed by her unexpected gesture that he fainted. Later she called for prosecutions of SS officers to stop, to allow them to come forward and to explain themselves. In this case we might say that a leap of intuition moved Eva Kor beyond the retributive passions to allow for new and creative possibilities which she argued would encourage other Nazis to come forward and to explain themselves.

These new beginnings, praxis and intuition have some self-sympathy for unbearable circumstances and an acknowledgment that crime is both a failing of the individual and the community, and therefore rehabilitation is the responsibility of both the individuals involved and the community. Bergson argues (Bergson, 1988) that normal feelings are caused by a representation of the other, whereas creative feelings create new representations: Our normal feelings for punishment and retribution are caused by the negative representation of the criminal whereas creative feelings grounded in forgiveness create the potential for hope and the projection of a positive image that might be actualized. Practically this means that forgiveness needs to be the starting point of rehabilitation rather than a mythical and elusive end point that in practice can rarely if ever materialize. For Bergson humans express new possibilities by enfolding new layers of habits which challenge and change the solidification and accretions that emerge from our connections with larger surrounding structures; there is a need for periods of in-determination when existing habits and practices are suspended and which allows for creative evolution (Bergson and Andison 2010); importantly we remember how that change has come about, what the change is relative to, however a new situation is actualized. 
Forgiveness is the dynamic space in which this enabled to happen. This does not and cannot take the form of a static, binary, platonic and idealised category (the latter is Derrida's conception of impossibility) but rather through praxis, natality or intuition it becomes an ethic of choice allowing possibility and potential to emerge from the practice of justice and which is explicitly committed to the past, present and future. Forgiveness is the space that emerges from the community as gift to both victims and perpetrators that: understands that a wrong has been committed and that there are victims and perpetrators; that victims' experiences are real, potentially traumatic and life changing and who demand justice and the expression of retributive passions; who understand or are prepared to understand their own propensity to violence and complicity in violence; who are prepared to offer a future for both victims and perpetrators for the benefit of the whole community ${ }^{11}$.

\section{Conclusion}

We have shown how a study of forgiveness can allow for the creation of new beginnings and potentialities for both individuals and society. The barriers to achieving this potentiality are achieved not by limitation and exclusion but only through a real reconceptualization of the new imagination of what is possible; insights into forgiveness that contrast with retributive principles provide such possibilities. The process of new beginnings in part involves a rereading of foundational texts and myths in the light of new scholarship and research, and that

\footnotetext{
${ }^{11}$ Truth and Reconciliation events around the world have sought to do just that and often through being presided over by a cleric, to varying degrees of success. The most famous being Archbishop Desmond Tutu in South Africa; there was controversy over whether he should wear his episcopal garb and with participants claiming that because of his presence and the symbolism of Christianity that they felt under pressure to forgive (see Brewer, Mitchell and Leavey, 2016) and that there was then something false about the process. Likewise research has shown (Colvin, 2000) that perhaps unsurprisingly reconciliation means different things to different people but that there was a perception that perpetrators of crime were being rewarded by the system in the form of amnesties and continued pensions but that the victims were still suffering the effects of apartheid and its atrocities. To stress the point forgiveness cannot be required but given the right conditions can be allowed to emerge over time.
} 
inform new methodologies and practices in doing justice. However in opening up new spaces for doing justice then we need to be cognizant of the historically determined factors that explain where we are now and a criminological hermeneutic that is informed by complexity theory and continental philosophy allows us to achieve this.

\section{Acknowledgements}

We would like to thank peer reviewers of earlier versions of this paper and also advice, comments and discussion from Prof Bruce Arrigo, Prof Anthony Bash and Father James Alison and Prof Andrew Millie. The paper was also the basis of presentations at the British Society of Criminology Annual Conference at Plymouth University and also the European Conference on Ethics, Religion and Philosophy (both in 2015) and we are indebted for the contributions from participants.

\section{Bibliography}

Allan, A. (2008) 'Functional Apologies in Law' in Psychiatry, Psychology and Law Vol.15(3): 369-381

Anscombe, E. (1958) ‘Modern Moral Philosophy’ in Philosophy Vol. 33(124): 1-19

Arendt, H. (1958) The Human Condition. Chicago. University of Chicago Press.

Arendt, H. (1961) Between Past and Future: Eight Exercises in Political Thought. New York. Vikin381

Aristotle (2004). The Nichomachean Ethics. London. Penguin Books

Armour, M. and Umbreit, M. (2005) 'The paradox of forgiveness in restorative justice' in E. Worthington The Handbook of Forgiveness. New York. Routledge: 491-504

Arrigo, B. and Barrett, L. (2008) 'Philosophical Criminology and Complex Systems Science: Towards a Critical Theory of Justice' in Critical Criminology 16: 165-184

Arrigo, B. and Williams, C. (2014) 'Complexity, law and ethics: On drug addiction, natural recovery and the diagnostics of psychological jurisprudence' in Pycroft, $A$ and Bartollas, $C$ 
(eds) Applying Complexity Theory: Whole systems approaches to criminal justice and social work. Bristol. Policy Press: 247-268

Augustine, St. (1958) City of God. London. Penguin Books.

Aulen, G. (2003) Christus Victor: An Historical Study of the Three Main Types of the Idea of Atonement. Wipf \& Stock Publishers

Azzam, A. (2015). Nietzsche versus Paul. New York. Columbia University Press

Badiou, P. (2003). St Paul: The foundation of universalism. Stanford. Stanford University Press.

Baker, J. and Booth, A., (2016) 'Hell to pay: Religion and punitive ideology among the American public' in Punishment and Society vol 18(2):151-176

Bartollas, C (2014) 'Constituting the system: Radical developments in post-Newtonian society' in Pycroft, A and Bartollas, C (eds) Applying Complexity Theory: Whole systems approaches to criminal justice and social work. Bristol. Policy Press: 269-286

Bash, A (2014) 'Forgiveness, Reconciliation and Spirituality: a Theological Perspective' in Journal for the Study of Spirituality 4(1): 58-72

Bash, A. (2015) Forgiveness: A Theology. Eugene, Oregon. Cascade Books

Bergson, H. (1971) Time and Free Will. London. George Allen and Unwin

Bergson, H. (1988) Matter and Memory. New York. Zone Books

Bergson, $\mathrm{H}$ and Andison, M. (2010) The Creative Mind. Whitefish. Kessinger Publishing Breton, S. (2011). A Radical Philosophy of St Paul. New York. Columbia University Press

Brewer, J., Mitchell, D. and Leavey, G. (2016) 'Northern Ireland: Religion and Transitional Justice' Conflict Studies Quarterly 14: 74-91

Byrne, D. (1998) Complexity Theory and the Social Sciences: An Introduction. London. Routledge

Byrne, D. and Callaghan, G. (2013). Complexity Theory and the Social Sciences: The state of the art. London. Routledge

Cilliers, P. (1998) Complexity and Postmodernism: Understanding Complex Systems. London. Routledge

Cilliers, P. (2005) 'Complexity, Deconstruction and Relativism' in Theory, Culture, Society Vol 22(5): $255-267$ 
Cohen, S (2016) 'Aristotle's Metaphysics' in Stanford Encyclopedia of Philosophy https://plato.stanford.edu/entries/aristotle-metaphysics accessed 30/6/17

Colvin, C. (2000). 'We Are Still Struggling': Storytelling, Reparations and Reconciliation after the TRC. Research report written for the Centre for the Study of Violence and Reconciliation in collaboration with Khulumani (Western Cape) Victims Support Group and the Cape Town Trauma Centre for Survivors of Violence and Torture, December.

Critchley, S. (2008) 'What is continental philosophy' in International Journal of Philosophical Studies 5(3): 347-365

Derrida, J. (2002). On Cosmopolitanism and Forgiveness. London: Routledge

De Valve, M. (2017a) 'O for a Muse of Fire: Rebellion as Sacrament' in Critical Criminology 25: 87-102

De Valve, M. (2017b) 'Love/Power' in Critical Criminology 25: 375-391

Downie, D.S. (1965) 'Forgiveness' in Philosophical Quarterly Vol.15(59): 128-134

Dupuy, J.P. (2013) The Mark of the Sacred. Stanford. Stanford University Press

Eddy, J. and Beilby, P (2006) 'The atonement: An introduction' in P. Beilby and J. Eddy (eds) The Nature of Atonement: Four Views. Illinois. IVP Academic: 9-21

Foucault, M. (1975). Discipline and Punish: The Birth of the Prison. London. Virago Books Frazier, J. (1922) The Golden Bough: A Study in Magic and Religion. London. Macmillan and co.

Girard, R. (2007) Evolution and Conversion: Dialogues on the Origins of Culture. London. Continuum Books

Girard, R. (2008) I See Satan Fall Like Lightening. Maryknoll. Orbis Books

Girard, R. (1978) Things Hidden Since the Foundation of the World. London. Athlone Press

Girard, R. (2014) The One by Whom Scandal Comes. East Lansing. Michigan University Press

Gorringe, T. (1996) God's Just Vengeance. Cambridge. Cambridge University Press

Griswold, C (2007) Forgiveness: A Philosophical Exploration. Cambridge. Cambridge University Press

Guastello, S. and Liebovitch, L. (2009)'Introduction to Nonlinear Dynamics and Complexity' in S.Guastello.,M.Koopmans and D.Pincus (eds) Chaos and Complexity in Psychology: The Theory of Nonlinear Dynamical Systems. Cambridge. Cambridge University Press: 1-40 
Hathaway, O. (2003). 'Path Dependence in the Law: the Course and Pattern of Legal Change in a Common Law System' John M. Olin Centre for Studies in Law, Economics, and Public Policy Working Papers. Yale Law School

Hawking, S. (1998). A Brief History of Time. Cambridge. Cambridge University Press

Johnstone, G. and Van Ness,D.W (2007) 'Roots of Restorative Justice' in Johnstone, G. and Van Ness,D.W (eds) Handbook of Restorative Justice. Cullompton. Willan: 109-111

Kearney, R. and Rainwater, M. (1996). The Continental Philosophy Reader. London. Routledge

Kearney, R. (1986) 'Religion and Ideology: Paul Ricoeur's Hermeneutic Conflict' in The Irish Theological Quarterly 52: 109-126

Kearney, R. (1999). 'Aliens and others: Between Girard and Derrida' in Cultural Values Vol 3 (3): 251-262

Kearney, R. (2016) Re-imagining the Sacred. New York. Columbia University Press

Kolnai, A. (1974) 'Forgiveness' in Proceedings of the Aristotelian Society, 1973-4: 91-106

Lacey, N. and Pickard, H. (2015) 'To blame or to forgive?: reconciling punishment and forgiveness in criminal justice' Oxford Journal of Legal Studies, online pp. 1-31 DOI: 10.1093/ojls/ggv012

Levinas, E. (1969). Totality and Infinity: An essay on exteriority. Pittsburgh. Dequesne University Press

Martin, D. (2014) Religion and Power: No Logos without Mythos. Farnham. Ashgate

Massumi, B. (1996) A user's guide to capitalism and schizophrenia: Deviations for Deleuze and Guattari. Cambridge. MIT Press

Melamed, Y. (2012) “"Omnis determinatio est negatio" - Determination, Negation and Selfnegation in Spinoza, Kant and Hegel' in Forster, E. and Melamed, Y. (eds) Spinoza and German Idealism. Cambridge. Cambridge University Press: 175-196

Menocal, M.R. (2002). The Ornament of the World: How Muslims, Jews and Christians Created a Culture of Tolerance in Medieval Spain. New York. Bay Back Books

Miller, J. (1990) 'Carnivals of atrocity' in Political Theory 18 (3): 470-491

Milanovanovic, D. (2014) Quantum Holographic Criminology: Paradigm Shift in Criminology, Law and Transformative Justice. Carolina Academic Press

Murphy, J. and Hampton, J. (1988) Forgiveness and Mercy. Cambridge. Cambridge University Press 
Nelson, M (1991) 'Utilitarian Eschatology' in American Philosophical Quarterly Vol. 28 (4): 339347

Nietzsche, F. (2008) The Birth of Tragedy. Oxford. Oxford University Press

Nietzsche, F. (2003) Thus Spoke Zarathustra. London. Penguin Books

Pellauer, D. and Dauenhauer, B. (2016) 'Paul Ricoeur' https://plato.stanford.edu/entries/ricoeur/ accessed 8/12/17

Pepinksy, H. (2013) ‘Peacemaking Criminology’ in Critical Criminology 21:319-339

Pycroft, A. and Bartollas, C. (eds) (2014) Applying Complexity Theory: Whole systems approaches to criminal justice and social work. Bristol. Policy Press

Pycroft, A (2014) 'Complexity theory: an overview' in Pycroft, A and Bartollas, C (eds) Applying Complexity Theory: Whole systems approaches to criminal justice and social work. Bristol. Policy Press: 15-38

Pycroft, A. (forthcoming) 'Consciousness In Rather than Of: Advancing Modest Claims for the Development of Phenomenologically Informed Approaches to Complexity Theory in Criminology. Journal of Theoretical and Philosophical Criminology.

Roberts, T. with Windle, J. (2015). Forgiven: The Amish School Shooting, a Mother's Love, and a Story of Remarkable Grace. Bloomington. Bethany House.

Sieh, E. (1989) 'Less Eligibility: The Upper Limits of Penal Policy' in Criminal Justice Policy Review Vol.3: 159-183

Sydow, J., Schreyogg, G. and Koch, J. (2009). 'Organizational Path Dependence: Opening the Black Box' in Academy of Management Review Vol 34(4): 689-709

The Guardian http://www.theguardian.com/commentisfree/2015/nov/03/i-was-able-toforgive-my-sisters-murderer-only-by-acknowledging-my-own-ange _accessed 30/6/17

The Guardian http://www.theguardian.com/world/2015/apr/27/auschwitz-survivor-angersplaintiffs-trial-forgiveness accessed 23/3/16 accessed 30/6/17

Verdeja, E. (2004) 'Derrida and the Impossibility of Forgiveness' in Contemporary Political Theory. Vol 3(1): 23-47

Žižek, S. (2011) Living in the End Times. London. Verso 